\title{
Bosnia and Herzegovina under the Communist Regime: an Outlook on Educational Policy
}

\section{Snježana Šušnjara ${ }^{a}$}

a University of Sarajevo, Faculty

of Philosophy

snjezana.susnjara@ff.unsa.ba

Received 28 October 2020

Accepted 12 February 2021

Available online 31 August 2021

DOI 10.15240/tul/006/2021-1-006
Abstract Bosnia and Herzegovina as one of the nine republics of Yugoslavia was always among the poorest republics in the former state. However, the school system, as it was the case in the totalitarian regimes, was under direct control of the state. The state had the power to influence school programs and to decide who could apply for school profession. After World War II, education became compulsory for all children and the state could have influenced easily all aspects of education. The state conception how to educate a new so-

ciety and how to produce a common Yugoslav identity was in focus of the new ideology and those who did not agree with this concept were exposed to negative connotations and even to persecution. Human rights of an individual were openly proclaimed but not respected. Totalitarian societies commonly expect the system of education to operate as a main transformational force that will facilitate the creation of the new man in the social order they have proclaimed. After the split of the Soviet model of pedagogy (1945-1949), the changes occurred in education when the communists established a new regime with universal characteristics of the Yugoslavian education which differentiated among the republics in accordance with their own specificities. Bosnia and Herzegovina with its multi-ethnic nature occupied a special place inside the common state as a model that served as a creation of possible, multiethnic, socialist Yugoslavia.

Keywords Communist regime, teachers, education, ideology, Bosnia and Herzegovina

\section{Introduction}

Bosnia and Herzegovina (BiH) were one of the republics of the newly established state after World War II, Yugoslavia. This new country started to build its society on a new ground in a difficult postwar situation. New political concept was introduced to the people and those 
who disagreed with it were forced to accept it or to leave. Many people disappeared after the war. There was only one political party, the Communist one. This party started to spread its ideological aims through education aiming to children as the most absorbing power. Children were educated to hate enemies (those who lost the war) and love partisans. This was black and white situation. Tito was the president of the Yugoslavia and was celebrated as the son of the nation. Children and youngsters used to repeat Tito's famous idea "Work as peace will always be here and be prepared as the war would start tomorrow", in accordance to the Latin expression Si vis pacem para bellum (If you want peace, prepare for war). My attempt is to discuss the general tendencies in the school system in $\mathrm{BiH}$ under the Communist regime as well as to uncover ideological inputs that stayed behind the official politics. Through the history, $\mathrm{BiH}$ was always exposed to the interests of those who ruled in this particular region (the Ottoman Empire, the Austro-Hungarian Monarchy, the Kingdom of Yugoslavia). Education was framed in accordance with the prevailed politics. $\mathrm{BiH}$ peoples were subordinated to diverse rulers and educational institutions only followed orders given by the current authorities. However, the politics was never created in the name of people as it was case in Yugoslavia. The principles of the new educational politics were formulated in a way that "school becomes institution for entire society and serves to its progress and liberation. School is free of the Church and religious influence and basis educational activity on science and Marxist theory. The whole society is interested for conditions of upbringing and education and through its representatives, it supports school to maintain this task" (Krneta, 1966, p. 184). The intention of the state politics was to construct the new system of education which would be completely divided from previous ones without influence of any religious. Therefore, the Communist Party's main goal was to establish new state as a secular, socialist and independent of any outside influences. In Yugoslavia, $\mathrm{BiH}$ was considered as a multicultural and multiethnic republic, religiously diverse including Catholics, Muslims, Christian Orthodox, and Jews. Therefore, it served as a good model for promoting the so-called 'brotherhood and unity' that was widely used ideological slogan referring 
to the formation of a multi-ethnic Yugoslavia (Lozić, 2015). There were two challenging narratives related to the construction of $\mathrm{BiH}$-identity, one "as a symbol of a united Yugoslavia", another as "a unique cultural heritage distinct from the neighboring states of Serbia and Croatia" (Alić \& Gusheh, 1999, p. 12).

\section{Influence of the SSSR on Yugoslavia}

The Yugoslav Federation was made in accordance with the model of SSSR. It followed this pattern in political, social and economic aspect of people's life. Tito's 'final solution' of national problem was a blind application of Soviet example. The Soviet federation was publicly proclaimed as the positive example of solving relations among peoples in the history of humanity. As one communist concluded: "It is true that we made first steps into the new federation by following Stalinist mode" (Vujica, 1972, p. 45). The socialist Yugoslavia institutionalised and recognised the national identities that were pre-existing in 1945 similar to the USSR. After 1945 Yugoslavia copied the Soviet constitutional arrangement and the principles of its implementation in reality (Brubaker, 1996, pp. 23-54). "The Communist Partisans, like other Marxists, were highly influenced by Stalin's work on the national question and the Yugoslavia that they constructed as a federation of republics in 1946 was modelled closely on the Soviet Union” (Carmichael, 2015, p. 95).

In accordance with this, schooling and education were strongly influenced by the Soviet pedagogy in Yugoslavia in the postwar period. Soviet authors were recommended and their books were imported and translated into a local language. Looking at the Soviet example, educational staff was united into the Trade union that was established after the war. Those who were in charge of this union informed that the number of teachers of the new type increased on a daily basis. The main task of the Trade Union was to promote the quality of educational work including the constant learning and struggling for better political instruction of the teaching staff (Vidović, 1946). The new regime diminished and ignored all educational efforts and results of previous regimes naming them as a formalism of the old school. They 
criticized verbalism, learning of definitions, formulas and facts (Begić, 1946). They claimed that new elementary school needed to be under the influence of a new spirit that would deal with a real life. This meant an introduction of the new contents and instruction of a teacher on how to educate children properly. Teachers' activity was controlled and observed by the inspector for education who evaluated their work. This gave an opportunity to the national authority to check on educational work and give a final word (Čaldarević, 1946). The authors of the magazine called Educational laborer, published in Sarajevo (1946-1949), who wrote about the situation in education used to quote Lenin or Stalin introducing school practice from the SSSR. Therefore, one of the authors quoted Lenin who claimed: "it is not possible to work without a plan, the longstanding plan for a serious success. Do not be afraid of longstanding plans: without them we cannot promote economic change. You should put all your strength in every place to fulfil this aim" (N. N., 1946, p. 27). In accordance with this proposition, a five years plan in education was promoted in SSSR. The same plan was supposed to be an example how to modernize education in Yugoslavia. There were two phases of the development of the school system and pedagogical theory promoted under the strong influence of the state ideology. First presented a development of socialistic pedagogy and schooling under direct Soviet influence until 1950s. Second phase meant a starting point of making a third path of self-managing socialistic pedagogy and schooling from 1951. The first phase suffered under complete domination of state ideology while the second phase recognized a slow decrease of state influence and politically proclaimed ideology (Radeka \& Batinić, 2020).

In a meantime, the Yugoslav new regime decided to stop its cooperation with SSSR and Stalin. Tito said his historical "no" to Stalin and Yugoslavia started to follow its own path in history. In December 1949, the Third Plenum of the League of the Communist Party of Yugoslavia (SK KPJ) introduced new qualities in education freed from the Soviet ideas. The policy makers set an account on dogmatization in science and pedagogy. They concluded that the aim of education was to form of an "universally educated free constructor of socialism, who is distanced 
from bureaucracy and narrow mindedness” (Subotić, 1984, p. 112). Nevertheless, the Yugoslav regime kept being a totalitarian one creating its own strategies and policies. It continued to control education and school functioning proposing a creation of the school programs by infiltrating ideology and ideas in every aspect of school activity. The regime distanced itself from the Soviet influence but created its own approach to the real life. The schoolbooks were full of war topics and glorification of the partisans and their battles. In every segment of the people's life this ideology was evident. The republic of Bosnia and Herzegovina was not an exception, quite the opposite. After dividing from the influence of soviet pedagogy, the intention of all educational subjects was to include more practical work in schools, focusing on the education of future laborers. An official uniformed educational policy that was full of normative tendencies did not permit any new initiatives within the educational practice (Šušnjara, 2015). It was declared "we need education which would prepare and educate our children for life in which only work and labor results define the position of human beings within society. The individual should be formed according to the Marxist standard and its world view. The school has an irreplaceable role in the development of self-managed socialistic awareness of the young generation. This is an important condition for the young generation if we want them to take over responsibility for further self-managed development of our society" (Mesihović, 1987, pp. 4-5). The communist government attempted to fill the people, especially youngsters, with a national and ideological consciousness using education and schoolbooks in an attempt to construct mindfulness, legitimize ideology, and shape everyday life and attitudes (Potkonjak, 1977). However, the whole educational system in the socialistic Yugoslavia was under continued supervision of the ideology that influenced and directed education. The school policy concept was completely monolithic one. There were only two ideas that dominated in all 50 years: unity of education as a symbol of social justice and generator of state identity and development of education in the self-managing system (Medveš, 2020, p. 65). 
The Marxist standard and its world-view were an example to follow. New makers of education glorified work and labor results as the only tools that would create a proper socialist man. Therefore, practical work in school was the preferred topic with an intention to create loyal future laborers. Leading politicians pointed out that intellectualism needed to be expelled from schools. More practical work was recommended. Consequently, children would be more physically active and trained to develop their potential. The school practice indicated that educational policy was uniformed and full of normative tendencies. Young generations were seen as the promoters of the self-managing society and they needed to be properly instructed and educated (Šušnjara, 2015). "The subject of students self-management should be defined by starting with general normative definitions of self-management (as a basic social relation), and later review a natural perspective on the role of students labor which they carry out, as well as from the position of their ages" (Bročić, 1972, p. 17).

Therefore, the leading politicians considered that children would be adequately educated in the conditions of self-management. They also thought that children needed to be under an integral care and influence of the labor class if they wanted them to be promotors and constructors of a modern socialistic society. There was also a need for teachers to be enlightened in this spirit because they had responsibility in transferring their knowledge to the students. Even though the self-managing society proclaimed the equality of everybody's work, the teachers' position was not changed very much in comparison to previous regimes, at least in $\mathrm{BiH}$. Thus, pedagogues discussed this issue pointing out that the status of educational laborers was not at the satisfying level. According to the law, education was considered as an activity of national importance, but teachers found themselves as hard working laborers not adequately recognized within society. Their material status was lower than of those who worked in other social spheres (Šušnjara, 2016). "The material position of the educational laborer was not at a satisfying level, even though the general law of education determined the educational sphere as an activity of major social importance. Therefore, such contradictory and unfavorable conditions provoked a belief 
concerning educational laborers that they were not adequately recognized socially and their material status was lower than that of others with the same qualifications within the social and economic spheres" (Ilić, 1989, p. 311). In spite of these objections, the material conditions of teachers did not considerably enhanced in the years that followed. The leading politician Rodoljub Čolaković gave an interview in 1983, expressing regrettably: "Today we have about 150,000 teachers. This in military terms is, 15 divisions and - imagine what they could have done if they consisted of enthusiastic individuals, members of the SKOJ! $!^{1}$ Do you know what power this is? [...] Yes, but look how badly teachers are paid! We do not call them teachers any more, but [...] I can't even say this word which has changed that beautiful teacher's name [...]" (Subotić, 1984, p. 239). The fact that Čolaković was the first prime minister of the new BiH Republic, a long-term Communist (Carmichael, 2015) and later on the minister of education did not improve teachers' status or situation in education as such. Up to 1990, politics in BiH was entirely dominated by former partisans (Carmichael, 2015).

\section{Bosnia and Herzegovina' Educational Efforts}

The years between 1945 and 1950 corresponded with a campaign of industrialization and collectivization, encouraged by the successes of similar programs in the Soviet Union. From 1946 onwards the republican authorities in Bosnia and Herzegovina began the construction of new school building and education of professionals. Through these efforts, the partisans aimed to bring children from different national groups and different social backgrounds together in a school in which they could learn from each other and be together. They also would receive appropriate exercise and political instruction related to important moments from the National Liberation Struggle. Regardless the way in which the state ideology changed after 1948, the transformative impulse in education lasted in some form until at least the middle of the 1950s. The development of education and teaching staff was 
a political-national necessity inseparably linked to the National Liberation Struggle (Yeomans, 2010).

$\mathrm{BiH}$ was among the poorest republics in the former state. It was mostly agricultural region nearly without industry. The school system was undeveloped and population was mainly illiterate. In 1941, more than $70 \%$ of population in Bosnia and Herzegovina was illiterate. In the periods before the war, the majority of people did not attend schools. At that time, Bosnia and Herzegovina did not have any faculty except the theological ones (Šušnjara, 2013). In order to ensure a necessary number of teachers, the authority founded the higher pedagogical school in Sarajevo in 1946. In 1948, there were only 4,000 highly educated persons in $\mathrm{BiH}$ (Bevanda, 2001, p. 106). The national government and its representatives made orations during the opening of this higher school emphasizing "the attempt of this school is to create a new type of teachers for secondary schools. Progressive, constructive and full of excitement this teacher would be a patriot who is tied up with his nation and his task is to educate youngsters and peoples in the spirit of the progress and love towards science, traditions of $\mathrm{NOR}^{2}$, homeland and nation and its healthy historical and cultural traditions" (Šamić, 1946, p. 14). Šamić (1946) also wrote that the best guarantee that the students of this school would be able to become teachers in two years is working and revolutionary élan that would overwhelm the entire population, especially youngsters. Every third adult resident was illiterate. During World War II, Bosnia and Herzegovina was destroyed and devastated without appropriate school network. From the beginning of the republic's development, the government recognized that there was a problem with a lack of trained and ideologically-conscious teaching staff (Šušnjara, 2013). Despite the longstanding plans, the lack of teachers was evident and delaying every further process in Bosnia and Herzegovina. The fact that some teachers lost their job because of their disagreement with the new ideology did not make this situation better. "These are not easy questions 
for the larger number of older teachers [...] for often the intentions are completely unfruitful when we are dealing with teachers who are principally and consciously against new concepts” (Papić, 1981, p. 104). The minister of education from the newly established government, Rodoljub Čolaković, encouraged this action claiming "pay more attention to constructing schools and short-term courses because it is better to have less qualified literacy courses as opposed to illiterate children" (Petranović et al., 1985b, p. 342). As a result of such a practice, children got poor education. Teachers who agreed to follow this instruction were also ready to follow the new ideas and to get a position. The same minister of education kept pointing out that the profession of teacher was very difficult profession and therefore teachers should be individuals who were aware of this fact. The new regime had power to influence school programs as well as to make a choice of school staff. Namely, a person who wanted to work as teacher had to be registered as the member of the Communist Party which was the only political party in Yugoslavia (Šušnjara, 2016).

Teachers were seen as promotors of the new models of living and behaving, especially because of their role in shaping the new generations. Thus, the new authority started with revolutionary changing of the society. Everything what reminded to the old system and society were proclaimed as 'bourgeoise', 'reactionary', 'decadent' and 'backward' (Dobrivojević, 2011, p. 7). In order to build a new socialist society and a 'socialistic' man, the struggle with the previous remains of the regime turn out to be a necessity. The political opponents became unwanted and persecution of those who were considered as 'radical' or 'dogmatic' started intensely. Intellectuals were under a special control. The new authority was afraid of their influence and ideas that they could promote among people. Education became a weapon in the political struggle during the process of creation a new socialist society (Šušnjara, 2016).

In other to bridge this gap, the authority organized short-term courses to train future teachers. About three-fourth of the accessible teachers after the war had finished a basic course instead the teacher training school. To address this, the Ministry for education invented 
a series of courses to train and educate teaching staff. There were numerous difficulties in implementation of these courses, not least of which was local resistance on both the administrative and individual level. One of the main obstacles was the attitude of the Regional People's Committees which had frequently not joined the "mobilization of youth" and had not sent the needed number of course participants "despite our reports and urgency" (Yeomans, 2010, p. 75). Government officials blamed older generations for this resistance of youth. They considered that youth inherited the primitive attitudes from them as well as negative attitudes towards education. Despite initially dallying of education accomplishments throughout of history, BiH persistently followed the course of education in Yugoslavia after World War II.

The first University in $\mathrm{BiH}$ was opened in 1949 and it was an opportunity for many students to attend various faculties. It was emphasized: "The establishment of the University in our Republic is a significant event in the history of our nation. This is not only important for our Republic but for all the people of Yugoslavia. On the one hand, the foundation of our University is so important in the terms of the paths and progress of Bosnia and Herzegovina throughout history. On the other hand, it is important in terms of the needs that our socialist homeland has for the professional and highly skilled staff, and above all, the needs of our man for cultural and educational improvement" (Papić, 1981, p. 181). Nevertheless, those who supported the regime and favorably followed the directives of various political commissars, who were hardly literate themselves, were the progressive ones. This was apparent due to the membership of the party's first university professional team consisting of famous war participants and party members who had "played a major role in bringing the youngest University of Yugoslavia into line with the most advanced institutions of higher education", as stated in the Regulation of the Divisions for faculties, adopted in 1950 (Službeni list BiH, 1950, p. 337). The idea of the unified school became an option towards the unification of the system including program and subject matters. Working school prevailed in the teaching as well as Herbartian approach. As Papić emphasized: "Just as the level of primary education is the most evident sign of the broadness 
in which the enlightenment of one nation has been based on, thus the university reflects the rise of the country in its educational and scientific achievement" (Papić, 1981, p. 181). The University was completely integrated and students of different religions studied together in Sarajevo. Later on, in the 1970s, universities were opened in Tuzla, Banja Luka and Mostar (Šušnjara, 2015; Carmichael, 2015).

The new regime mainly focused on youngsters through education. The party made it clear that old customs (such as traditional dress of $\mathrm{BiH}$ women, ethnic and religious customs) had to be exterminated. They were considered as a sign of oppression and new society needed to accept modern visions of living. The state encouraged matrimonial relations across ethnic lines, free of religious influence. Therefore, mixed marriages were stimulated positively and a large percentage of the leading political elite in $\mathrm{BiH}$ were in mixed marital partnership. Such an ideological understanding of social reality had intention to eliminate ethnic identity or class privilege (Ančić, 2004). The idea was to create "the ethnically mixed Bosnia and Herzegovina, in which no nation can claim titular status [...] as a region with different religions but one nation" (Burić, 2010, p. 234).

\section{The Constant Lack of Teaching Staff}

There were seven teacher training schools in BiH in 1948: Mostar, Sarajevo, Travnik, Bihać, Banja Luka, Tuzla and Derventa with 1600 pupils. Teachers used to get their diplomas at Higher Pedagogical School and Faculty of Philosophy. The five years plan ordered that after finishing teacher training schools, candidates had obligation to be at service to the people and homeland. This task was given to youngsters by comrade Tito's message: "We need to send a huge number of youngsters to teacher training schools in order to ensure future generation of teachers” (Đikić, 1948, p. 6). Nevertheless, at the end of the 1960s, BiH still faced the same problem in not providing enough of its own teachers. Therefore, teachers were imported from other parts of Yugoslavia, particularly from Serbia and Montenegro (Dizdar \& Bakaršić, 1996).

An increased need for teaching profession went together with the increasing need for laboring force of other professions, such as engineers, 
doctors and agronomists. Accordingly, it was important to establish secondary schools for these professions as well. Hence, there were complains that the process of resolving illiteracy had to be priority as well as the founding of primary and secondary schools that were still lacking. There were even protests related to the process of establishing many faculties, in a time when more than $50 \%$ of children did not join primary school, or more than $60 \%$ of adults were illiterate (Papić, 1981). Furthermore, there were about 39 municipalities in $\mathrm{BiH}$ without a primary school on its territory, or if they succeeded to organize school functioning, the quality of the teaching staff was insufficient. Approximately three-fourths of the teachers had completed a basic teaching course instead of a teacher training school (Petranović et al., 1985a).

The compelled establishment of elementary schools without suitable teaching staff and material and substantial objective conditions influenced considerably pupils' educational achievements. "It was not a rare case that the sixth classes were founded in the school hallways, without the most basic teaching aids and equipment. There were usually three educators so that their working time lasted for 8 or more hours. Moreover, if we add the period of preparation for classes, then the figure rises to 12 hours per day, which exceeds the real possibilities and norms of these teachers. In such conditions where one teacher is in charge of 2 departments and teaches 10 or more hours of part-time, it is impossible to achieve quality" (Ivanić, 1963, p. 5). Up to 1964/65, the post-war expansion of education in $\mathrm{BiH}$ showed significant characteristics: an important increase of all educational institutions, pupils and students; the solid development of secondary and higher education; and slow development of primary education (Milišić, 2007). Consequently, whole school system faced a crisis in 1967 . The primary school system that had a special significance for social development suffered a lot. The dispersion of students from the first to the eighth grades rapidly emerged. Just about half of the students from the fifth grade were not able to finish primary school in eight years. Dispersal started in the fifth grade when pupils were not able to adjust themselves to a greater number of teachers and dissimilar teaching methods. Moreover, the many parents regard as a primary school a four-year 
school. They also considered secondary schools as higher grades that children from rural areas did not really need (Šušnjara, 2013, p. 101).

\section{Enduring Problem of Illiteracy}

According to the Statistic data from 1973, BiH had 672,000 (23.2\%) illiterate population in the age of 10 and more. By comparison of this data with the number of inhabitants in $\mathrm{BiH}(3,746,000)$ it is evident that every sixth inhabitant was illiterate. Even Sarajevo as a capital city had 18,000 illiterate citizens (Nikić, 1973a, p. 2). This continuous occurrence of illiteracy confused educational workers, especially the fact that 122,000 illiterate people was in the age of 10-34. The number of illiterate people in the age of 35-64 had been reduced symbolically. Namely, a majority of the villagers, especially women, avoided alphabetical courses or attended them irregularly. The party officers also acknowledged that alphabetical courses were "mostly running for numbers than the real status of those made literate" (Dobrivojević, 2011, pp. 14-15). In reality, there were numerous examples about people who forgot how to read and write were asked to take the course again and afterwards were reported as literate once more (ibid., 2011). This group included about $30 \%$ of the active population. Villages noted an alarming number of illiterate people $(589,280$, about $90 \%)$, while 65,540 or $10 \%$ of urban population was also illiterate. However, a deeper analysis would discover the real situation, every eleventh citizen and every fourth peasant were illiterate (Nikić, 1973b). Female population was also a large problem. From the total number of female inhabitants in $\mathrm{BiH}, 34.63 \%$ were illiterate, almost every third woman was illiterate. The number of illiterate women in the age of $10-19$ was $4.60 \%$ or 23,582 women, in the age of $20-34-15.33 \%$ or 78,590 women. In total sum, there were $19.93 \%$ or 102,172 illiterate women in the age of 10-34 (D. G, 1973). "This is too much. These women are mostly mothers or they intended to be. They are first educators of youngsters. Therefore, it is a large problem. Even literate people have problems to follow modern life directions. How can we ask this from illiterate mothers who are expected to offer some explanations to their children in order to 
help them even in a situation when they are not capable to do so?!” (D. G, 1973, p. 4).

Table 1. Illiteracy of women in 1973

\begin{tabular}{llll} 
Women in 1973 & Age 10-19 & Age 20-34 & Age 10-34 \\
\hline Illiterate & 23,582 & 78,590 & 102,172 \\
\hline
\end{tabular}

The problem of illiteracy was not only a result of "a cultural heritage" but it was the equivalent of an unfortunate history and "the darkness of the occupations that oppressed our poor people” (Šipovac, 1975, pp. 531-536). Šipovac declared that an illiterate man "is not a complete person, neither in his family, neither in production nor in the whole of society. Illiteracy is the real illness of our social sphere of life; it is one that has the biggest and darkest pains" (ibid., p. 536). Even though some constructive efforts evidently were taken in order to increase literacy, young people and the working class were mostly illiterate. "In this moment of our socialistic development, illiteracy cannot be tolerated. An autonomous society requests conscious citizens who need to be educated in order to contribute to their development" (ibid., p. 534). Therefore, it was concluded that illiteracy was not simply the concern of educational institutions but a problem of the entire society. It is important to emphasize that in 1975, from 109 municipalities of $\mathrm{BiH}$, half of them had the status of economically undeveloped areas. Therefore, a majority of these areas got $70 \%$ financial support from the Republic to build elementary schools, whereas developed municipalities sponsored this process from their own financial resources. (Hromadžić, 1982, p. 4).

\section{Ideologization through Education, Example of Tito's Pioneers}

As mentioned before, during the construction of the new state, $\mathrm{BiH}$ was often presented as 'Jugoslavija u malom' (miniature Yugoslavia) because of its multiethnic character. Therefore, this republic represented a unique opportunity to political observant to see how education 
could be advanced and modified within the context of great state-building efforts in an ethnically varied society (Lanahan, 2017). The Communist experiment of 'brotherhood and unity' was much more successful and well applied in $\mathrm{BiH}$, more than anywhere in Yugoslavia. As it was already mentioned, education was seen as an appropriate tool for creating new citizens and loyal members of the socialistic society. Schoolbooks, poetry, literature, physical activities, arts, excursion, all of these school activities were colored by the present ideology and glorified Tito as the biggest son of the Homeland. Schoolbooks dealt with outstanding nation's spirit based on the epic traditions of Yugoslav past, particularly the traditions of the People's Liberation War. Children had to learn about heroic battles and important dates from new history. Pupils participated at the competitions during the manifestation known as Tito's revolutionary trails (Batinić, Radeka \& Šušnjara, 2016).

Example of the continuous impact of the ideology was obvious in the process of initiation of small children into Tito's pioneers. Namely, children from the first grade were initiated into Tito's pioneers and stayed there until they become old enough to commence with a new role, one of the Tito's youngsters. Pioneers did not have any alternative. Then, they could have become members of the Socialist Communist Youth of Yugoslavia. Everything served for spreading ideological ideas of the Communist regime. The very word PIONEER was an acronym Persevering, Industrious, Open-minded, Noble, Earnest, Enlightened and Reliable (Batinić, Radeka \& Šušnjara, 2016). In practice, Yugoslav socialism involved a reduction and suppression of people's rights. The Communist Party, police, and secret service were the main tools of implementation of this regime. Education was seen as the place where reinforcement of ideological approaches could have found its place. Therefore, the collective socialist consciousness was applied through Pioneer and Youth organizations (Ognjenović \& Jozelić, 2016).

The Communist regime found power of words as very influential and good in promotions of their ideas. With constant repeating of these words the state succeeded to connect the greatest terms in political dictionary with their own movement. When someone listened or read terms such as: freedom, progress, democracy, patriotism, nation, 
national, it seems that they were made just to describe communism and its aims (Vujica, 1972). Therefore, they created slogans which had an important role in enforcing the communist ideology and promoting a personality cult. The slogans were elements of school decorations, especially during various celebrations. The slogans like "Death to fascism - freedom to the people!”, “Tito, the Party, the Youth, the action!”, "We are all Tito!”, “We belong to Tito, Tito belongs to us!”, “Brotherhood-unity!" were yelled by children, without understanding of their sense or connotations. Pupils and students were involved in different programs celebrating various occasions and they sang or recited songs and poems which glorified Tito and his distinguished role in the war. He was presented as the hero who fought for their better future and position in the world liberated from the bourgeoisie and removed from the bad capitalist world. Children's songs projected for festive occasions had a stronger influence on pupils and had an additional significant purpose - creation of enjoyment and pride to live in such country (Batinić, Radeka \& Šušnjara, 2016). Symbols were also instrumentalized for political aims to shape the public perception. Red star was the main symbol and its supremacy was absolute. Even BiH's flag became a symbol of this Republic's specificity, a red flag with a small Yugoslav flag in the corner pointing out in this way that this republic is an actual copy of the main state.

Ideological and political learning was a part of education. Political decisions were present in every aspect of schools' life. The prominent professionals of that time invested in the schools "comrade Tito's thoughts on education”. Professor at faculties quoted Tito's ideas or thoughts as "motivation and a warning regarding what was recommended to be done and what was not allowed" (Šušnjara, 2015, p. 85). Nikola Filipović, professor at the Department of Pedagogy, University of Sarajevo, claimed that Tito had a knowledge how to make strong interaction between the party's policy and pedagogy. He explained that the reason for this laid in fact "[...] the domination of policy over pedagogy was 'cultivated' and accepted as normal fact which had a positive effect towards understanding the behavior of political and professional 
employees in ministries, committees and boards, as well as pedagogues in different institutions" (Filipović, 1971, p. 512).

Even the free time of children was under the influence of politics aiming to correctly develop their abilities and to shape them properly in accordance with the proclaimed educational goals. In reality, questions about free time and leisure were profoundly ideological, with the different kinds of a reading material. Magazines for children and youth always "give a special attention to education [...] and very precisely indicate the ideological, moral and other aims that they want to present and root into new generations" (Javor, 2010, p. 3). Pupils were encouraged to read at least one children magazine (Vesela sveska, Male novine, Modra lasta) that dealt with school issues and usually presented national and state holidays, explaining their significance supported by children paintings or poetry (Batinić, Radeka \& Šušnjara, 2016). These magazines presented contents in the spirit of the social times in a way suitable for children and youth to understand. Thus, they were able "to be engaged in indirect, implicit and 'seductive' education" (Lončar, 2019, p. 25). Free time and leisure were wider political, social, and cultural streams and were innately linked. Apart of the schools and other educational and cultural institutions, other factors of socialistic education needed to influence children free time, such as magazines, radio or TV (Potkonjak, 1977). At the same time, ideology still played an important role in the school itinerary and extracurricular activities, including competitions as well as national and partisan dances. Erdei (2006) claimed that only correctly ideologically influenced children and youth could be a seed of a better future and guarantee a lead of the historical development in the right direction. $\mathrm{BiH}$ was a polygon of such an effort and this could be a reason why Yugo-nostalgia is still very much present in this country where echoes of the Socialist past were louder than in other former republics.

\section{Conclusion}

As it was presented, the state-wide project did not recognize borders between formal and informal education, or between family, school and social life. Everyone was expected to work towards the same 
goal in educating the new Yugoslavian man of socialist orientation in accordance with the declared ideology of the Communist Party in all republics. Education was subordinated to undemocratic ideological requests of a single-party state. The republics had to follow instruction given by the main authority and the same contents and beliefs were presented to the children. There was no alternative to such education or exclusion from some festive occasions organized by school. Children were a small army in the hand of the dominant party that controlled every step of people's movement. Certain political experts perceived $\mathrm{BiH}$ as a proper place for checking Yugoslav concept because of its multi-ethnic nature. Therefore, they used to call this Republic as a small Yugoslavia (Kamberović, 2018, Lučić, 2008). Because of its specificity, $\mathrm{BiH}$ was under the constant influences of political interests that encouraged certain actions that were not so much present in other republics. From abovementioned facts, it was evident that the primary education developed slowly in $\mathrm{BiH}$ which then reflected to other aspects of people's life, interests and choice of future career. Position of teachers kept being underestimated and not adequately recognized in the society. People, especially those from rural regions, were unenthusiastic to send their children to the schools after they completed four-year education. However, the authority made a lot of efforts to explain the importance of education to its citizens. The pioneer and youth organizations were in charge to attract education to their peers from distant regions. They organized some festive events and social circles as well as sport activities. In $\mathrm{BiH}$ "modern foundations of basic education were being placed, significantly weakening these elementary efforts due to the materialistic and political difficulties, social prejudices and more or less indifference of the middle class” (Babić \& Kovačević, 2000, p. 6). Despite all these actions and promotions, illiteracy maintained as a constant and longstanding problem in $\mathrm{BiH}$. Unfortunately, female population in rural regions were mostly deprived in regard to this issue. A social aspect of this phenomena showed that $\mathrm{BiH}$ required higher investment in education and changes in public perception of education as an essential tool for prosperous life. As Kamberović claimed "because of the fact that modernized processes were not an input in all social 
spheres (especially politics), it was discovered at the end of this period that the Bosnian society did not go over the borders of traditionalism and therefore, did not enter into the category of modernized societies" (Kamberović, 2000, p. 185). The period of socialism left imprisoned in the memory of $\mathrm{BiH}$ inhabitants looking for the experts to investigate it properly.

\section{Literature}

ALIĆ, Dijana \& GUSHEH, Maryam, 1999. Reconciling National Narratives in Socialist Bosnia and Herzegovina: The bašcaršija project, 1948-1953. Journal of the Society of Architectural Historians. 58:1, pp. 6-25.

ANČIĆ, Mladen, 2004. Society, Ethnicity, and Politics in Bosnia-Herzegovina. Časopis za suvremenu povijest. Vol. 36, No. 1, pp. 331-359.

BABIĆ, Anto \& KOVAČEVIĆ, Desanka, 2000. Prilog o historiografiji srednjovjekovne Bosne i Hercegovine. Most. Vol. XXVI, No. 131, Mostar, pp. 73-79.

BATINIĆ, Štefka, RADEKA, Igor \& ŠUŠNJARA, Snježana, 2016. Today, as I become a Pioneer...: Education in the Spirit of Socialism. Historia scholastica. No. 1, pp. 42-63. ISSN 2336-680X.

BEGIĆ, Midhat, 1946. Predviši i niži tečajni ispit. Prosvjetni radnik. No. 1, pp. 4-6.

BEVANDA, Mladen, 2001. Pedagoška misao u Bosni i Hercegovini od 1918. do 1941. godine. Sarajevo: Filozofski Fakultet. ISBN 9958-625-03-2.

BEVANDA, Mladen, 2005. Doprinos prof. dr. Nikole Filipovića povijesti pedagogije i školstva u BiH. In: Zbornik radova Nikola S. Filipović i njegovo djelo. Sarajevo: Filozofski fakultet, pp. 118-121

BROČIĆ, Miodrag, 1972. Mladi danas i sutra. In: ARSLANAGIĆ, Razija, DIZDAREVIĆ, Ismet \& MANDIĆ, Petar (eds.). Vaspitanje samoupravljanjem. Sarajevo: Zavod za izdavanje udžbenika, pp. 11-19.

BRUBAKER, Rogers, 1996. Nationalism Reframed: Nationhood and the National Question in the New Europe. United Kingdom: Cambridge University Press. ISBN 9780511558764

BURIĆ, Feđa, 2010. Dwelling on the Ruins of Socialist Yugoslavia: Being Bosnian by Remembering Tito. In: TODOROVA, Maria \& GILLE, Zsuzsa. Post-communist Nostalgia. New York: Berghahn Books, pp. 227-243. ISBN 978-1-84545-671-9.

CARMICHAEL, Cathie, 2015. A Concise History of Bosnia. United Kingdom: Cambridge University Press. ISBN 9781139060134.

ČALDAREVIĆ, Mitar, 1946. Pregled rada učitelja osnovnih škola. Prosvjetni radnik. No. 1, pp. 6-8. 
D. G., 1973. Da li je nepismenost aktualnost BiH. Prosvjetni list. No. 418, p. 4.

DIZDAR, Srebren \& BAKARŠIĆ, Kemal, 1996. Report on Higher Education in Bosnia and Herzegovina: Historical Development, Present State, and Needs Assessment. Bucharest: CEPES.

DOBRIVOJEVIĆ, Ivana, 2011. Od ruralnog ka urbanom, modernizacija Republike Bosne i Hercegovine u FNRJ 1945-1955. In: Zbornik radova Identitet Bosne $i$ Hercegovine kroz historiju. Sarajevo: Institut za historiju. Vol. 2, pp. 7-26. ISBN 978-9958-649-10-3.

ĐIKIĆ, Hasan, 1948. Za upis omladine u učiteljske škole. Prosvjetni radnik. No. 4, pp. 1-6.

ERDEI, Ildiko, 2006. "The Happy Child” as an Icon of Socialist Transformation. In: LAMPE, John \& MAZOWER, Mark (eds.). Ideologies and National Identities. Budapest: Central European University Press, pp. 154-179. eISBN 9786155053856.

FILIPOVIĆ, Nikola, 1971. Odnos pedagogije i politike u vremenu od 1945-1970. Naša škola. No. 9-10, pp. 511-525.

FRANKOVIĆ, Dragutin, 1950. O socijalističkom moralu i odgoju novog čovjeka. Zagreb: Centralno narodno sveučilište.

HROMADŽIĆ, Midhat, 1982. Prevladan najveći problem u osnovnom obrazovanju. Prosvjetni list. No. 655, p. 4.

ILIĆ, Mile, 1989. Periodizacija razvoja pedagoške nauke u Bosni i Hercegovini (1945-1980). Naša škola. No. 3-4, pp. 97-113.

IVANIĆ, Ljubomir, 1963. O nekim uzrocima slabog uspjeha učenika završnih razreda osnovne škole. Prosvjetni list. No. 212, p. 5.

JAVOR, Ranka, 2010. Uvodna riječ. In: JAVOR, Ranka (ed.). Časopisi za djecu i mladež. Zagreb: Knjižnice grada Zagreba, pp. 3-4. ISBN 978-953-6499-59-5.

KAMBEROVIĆ, Husnija, 2000. Prema modernom društvu. Tešanj: Centar za kulturu i obrazovanje.

KAMBEROVIĆ, Husnija. Sto godina Jugoslavije. In: Radio Slobodna Europa. Available at: https://www.slobodnaevropa.org/a/specijal-100-godina-jugoslavije-husnija-kamberovic/29561567.html 2018.

KRNETA, Ljubomir, 1966. Prilozi nastavi pedagogije. Beograd.

LOZIĆ, Vanja, 2015. (Re)Shaping History in Bosnian and Herzegovinian Museums. Culture Unbound. Vol. 7, pp. 307-329.

LANAHAN, Brian, 2017. Post-Conflict Education for Democracy and Reform: Bosnian Education in the Post-War Era, 1995-2015. Palgrave Studies in Global Citizenship Education and Democracy. London: Palgrave Macmillan. ISBN-13: 978-1137576118. 
LONČAR, Mateja, 2019. Odgoj u Modroj lasti između izgradnje socijalističkog čovjeka i tinejdžerske self-help literature (1966-1976). Anali za povijest odgoja. Vol. 17, pp. 7-25.

LUČIĆ, Ivica, 2008. Bosna i Hercegovina od prvih izbora do međunarodnog priznanja. ČSP. No. 1, pp. 107-140.

MANIĆ, Ljiljana, TORLAK, Nada \& SIMEUNOVIC BAJIC, Nataša, 2011. Tito, Yugoslavia and the "Third Way": Understanding Physical and Symbolic Borders. Eurolimes. No. 11, pp. 55-63.

MEDVEŠ, Zdenko, 2020. Socijalistička pedagogija uhvaćena u mit o pravednosti jedinstvene škole i kulturnu hegemoniju. In: PROTNER, Edvard (ed.). Razvoj $i$ aktualne tendencije pedagogije $i$ školstva na području nekadašnje Jugoslavije. Maribor: University of Maribor Press, pp. 61-106. ISBN 978-961-286-321-0.

MEDVEŠ, Zdenko, 2015. Socialist pedagogy: Caught between the Myth of the Fairness of the Unified School and Cultural Hegemony. Journal of Contemporary Educational Studies. No. 2, pp. 14-41. ISSN 00380474.

MESIHOVIĆ, Munir, 1987. Pozdravna riječ na svečanoj akademiji povodom 100 godina učiteljstva u Bosni i Hercegovini. Naša škola. No. 1-2, pp. 3-5.

MILIŠIĆ, Senija, 2007. Razvoj prosvjete, nauke i kulture u Bosni i Hercegovini, 1945-2003. In: Filipović, M. (ed.). Naučni skup Bosna i Hercegovina prije i nakon ZAVNOBiH-a. Sarajevo: Akademija nauka i umjetnosti Bosne i Hercegovine. ISBN 978-9958-601-20-0.

N. N., 1946. U SSSR i škole postavljaju svoj petogodišnji plan. Prosvjetni radnik. No. 1, p. 27.

NIKIĆ, Nikola, 1973a. A što je s nepismenošću?. Prosvjetni list. No. 414, p. 2.

NIKIĆ, Nikola, 1973b. Nepismenost ipak aktualnost u BiH. Prosvjetni list. No. 417, p. 2.

OGNJENOVIĆ, Gorana \& JOZELIĆ, Jasna, 2016. Titoism, Self-Determination, Nationalism, Cultural Memory. Vol. 2, Tito's Yugoslavia, Stories Untold. New York: Palgrave Macmillan. ISBN 978-1-137-59747-2 (eBook).

PAPIĆ, Mitar, 1981. Školstvo u Bosni i Hercegovini, 1941-1955. Sarajevo: Svjetlost. PETRANOVIĆ, Branko, KONČAR, Ranko \& RADONJIĆ, Radovan, 1985a. Sednice Centralnog komiteta KPJ (1948-1952). Beograd: Izdavački centar Komunist (Izlaganje Avde Hume na Trećem plenumu SK KPJ, n. d. 352).

PETRANOVIĆ, Branko, KONČAR, Ranko \& RADONJIĆ, Radovan, 1985b. Sednice Centralnog komiteta KPJ (1948-1952). Beograd: Izdavački centar Komunist. (Izlaganje Rodoljuba Čolakovića na Trećem plenumu CK KPJ, n. d. 342).

POTKONJAK, Nikola, 1977. Od etatističke ka samoupravnoj socijalističkoj osnovnoj školi. Beograd: Prosveta. 
RADEKA, Igor \& BATINIĆ, Štefka, 2020. Pedagogija i školstvo u Hrvatskoj od završetka Drugog svjetskog rata do kraja 1950-ih. In: PROTNER, Edvard (ed.). Razvoj i aktualne tendencije pedagogije i školstva na području nekadašnje Jugoslavije. Maribor: University of Maribor Press, pp. 107-130.

ISBN 978-961-286-321-0.

SUBOTIĆ, Gavrilo, 1984. Pedagoške misli Rodoljuba Čolakovića. Naša škola. No. 3-4, pp. 232-240.

Službeni list BiH, 1950. No. 40, p. 337.

ŠAMIĆ, Midhat, 1946. O radu i zadacima Više pedagoške škole u Sarajevu. Prosvjetni radnik. No. 1, pp. 12-15.

ŠIPOVAC, Neđo, 1975. Nepismenost-bauk prošlosti i sadašnjosti. Naša škola. No. 9-10, pp. 531-536.

ŠUŠNJARA, Snježana, 2016. Pedagogy of Bosnia and Herzegovina between Past and Future. Journal of Contemporary Educational Studies. No. 3, pp. 86-103. ISSN 00380474.

ŠUŠNJARA, Snježana, 2015. Development of School Systems and Pedagogy in Bosnia and Herzegovina from the Period after World War II to the 1970s. Journal of Contemporary Educational Studies. No. 2, pp. 78-94. ISSN 00380474.

ŠUŠNJARA, Snježana, 2013. Razvoj specijalnog školstva u Bosni i Hercegovini od 1958. do 1990.godine. Zagreb-Sarajevo: Synopsis. ISBN 978-953-7968-00-7.

VIDOVIĆ, Danilo, 1946. S novim radnim poletom pripremamo se za naš kongres. Prosvjetni radnik. No. 1, pp. 2-3.

VUJICA, Mirko Stanko, 1972. Kroz izbjegličku prizmu. Munchen-Barceolona: Knjižnica Hrvatske Revije.

YEOMANS, Rory, 2010. From Comrades to Consumers: Holidays, Leisure Time, and Ideology in Communist Yugoslavia. In: Yugoslavia's Sunny Side: A History of Tourism in Socialism, 1940s-1980s. Central European University Press, pp. 69-106. ISBN 978-963-9776-69-2. 